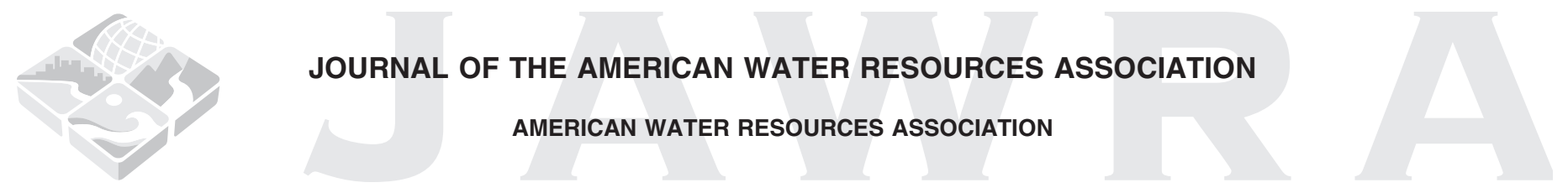

\title{
ERROR AUTOCORRELATION AND LINEAR REGRESSION FOR TEMPERATURE-BASED EVAPOTRANSPIRATION ESTIMATES IMPROVEMENT ${ }^{1}$
}

\author{
Patrick Valverde Medeiros, Francisco Fernando Noronha Marcuzzo, Cristián Youlton, and Edson Wendland ${ }^{2}$
}

\begin{abstract}
Estimates of evapotranspiration on a local scale is important information for agricultural and hydrological practices. However, equations to estimate potential evapotranspiration based only on temperature data, which are simple to use, are usually less trustworthy than the Food and Agriculture Organization (FAO)Penman-Monteith standard method. The present work describes two correction procedures for potential evapotranspiration estimates by temperature, making the results more reliable. Initially, the standard FAOPenman-Monteith method was evaluated with a complete climatologic data set for the period between 2002 and 2006. Then temperature-based estimates by Camargo and Jensen-Haise methods have been adjusted by error autocorrelation evaluated in biweekly and monthly periods. In a second adjustment, simple linear regression was applied. The adjusted equations have been validated with climatic data available for the Year 2001. Both proposed methodologies showed good agreement with the standard method indicating that the methodology can be used for local potential evapotranspiration estimates.
\end{abstract}

(KEY TERMS: evapotranspiration; hydrology; FAO-Penman-Monteith; Jensen-Haise; Camargo.)

Medeiros, Patrick Valverde, Francisco Fernando Noronha Marcuzzo, Cristián Youlton, and Edson Wendland, 2011. Error Autocorrelation and Linear Regression for Temperature-Based Evapotranspiration Estimates Improvement. Journal of the American Water Resources Association (JAWRA) 1-9. DOI: 10.1111/j.17521688.2011.00614.x

\section{INTRODUCTION}

The water transference between the terrestrial surface and the atmosphere occurs by two ways: in the atmosphere-surface direction, where the precipitation can be in any physical state, in the form of rain, hail, and snow; and in the surface-atmosphere direction where water transference occurs in the vapor form, due to evaporation and perspiration of biological origin. The summation of the evaporation and transpiration phenomena usually is called evapotranspiration (ET).
A large number of methods and equations aiming to estimate evapotranspiration are available (Jensen et al., 1990). Due to the large variability of parameters that influence the phenomenon, and also due to the fact that many of these models are empirical, researchers (Liu and Kotoda, 1998; Lu et al., 2005; Ross et al., 2005; Sumner, 2006; Wendland et al., 2007; Barreto et al., 2009) generally compare the results of different methods to evaluate which one has better applicability to the study place. López-Urrea et al. (2006) evaluated seven models of daily evapotranspiration calculation in comparison to one lysimeter in the Province of Albacete, in Spain. The authors

\footnotetext{
${ }^{1}$ Paper No. JAWRA-10-0203-P of the Journal of the American Water Resources Association (JAWRA). Received November 20, 2010; accepted September 12, 2011. ( ) 2011 American Water Resources Association. Discussions are open until six months from print publication.

${ }^{2}$ Respectively, Graduate student (Medeiros, Marcuzzo, Youlton) and Professor (Wendland), Department of Hydraulics and Sanitary Engineering, University of São Paulo, Av. Trabalhador Sancarlense 400, São Carlos-SP 13566-590, Brazil; and Senior Hydrologist, (Marcuzzo), CPRM - Geological Survey of Brazil, Brazil's Mines and Energy Ministry, Goiânia-GO 74170-110, Brazil (E-Mail/Wendland: ew@sc.usp.br).
} 
concluded that the Food and Agriculture Organization (FAO)-Penman-Monteith method had high accuracy in estimating potential evapotranspiration (ETp), compared with the lysimeter measurements. $\mathrm{Xu}$ and Chen (2005) evaluated seven models of the potential evapotranspiration estimate and its performances in the study of water balance in comparison with lysimeters using hydrological data of the meteorological station of Mönchengladbach, in Germany. The authors concluded that the Granger and Gray (1989), Thornthwaite (1948), Makkink (1957), and Priestley and Taylor (1972) methods presented similar good results with errors below $10 \%$ for groundwater recharge calculation through water balance. Chiew et al. (1995) evaluated the performance of potential evapotranspiration estimates with data from 16 Australian stations. The Penman FAO-24 method overestimated the potential evapotranspiration estimate by PenmanMonteith by 20 to $40 \%$. On the other hand, the Radiation FAO-24, Blaney-Criddle FAO-24, and PenmanMonteith methods obtained similar potential evapotranspiration monthly estimates. Pereira and Pruitt (2004) compared potential evapotranspiration estimated by the Thornthwaite equation modified by Camargo et al. (1999) with FAO-Penman-Monteith for two distinct environments, the Mediterranean climate of Davis (California) and Piracicaba (Sao Paulo State, Brazil) with humid summer and dry winter. Results obtained with the modified Thornthwaite method were as good as FAO-Penman-Monteith estimates. Estimates obtained with the mean daily temperature and estimates based only on the photoperiod mean temperature did not show large differences.

The Penman-Monteith equation is recognized as the standardized methodology in the FAO-56 bulletin (Allen et al., 1998). This equation not only considers the aerodynamic and thermodynamic aspects, but also includes the resistance to the flow of sensible heat and water vapor, and the resistance of the surface (plant) to the water vapor. Jacobs (2001) affirms that equations of combined type present the best results for a large variety of vegetated surfaces and climates, and its application is recommended. However, the calculation is laborious and the necessary climatic variables require a large amount of instrumentation, which is not always available, mainly in ungauged basins.

Our hypothesis is that empirical equations based only on daily temperature and global radiation data are a first approximation to estimate the potential evapotranspiration. We assume that the difference between these methods and real potential evapotranspiration results from systematic errors that can be identified by statistic analysis. If such equations using few parameters can be adjusted locally, a good alternative to more sophisticated methods can be provided.
In this article, a procedure attempting to improve the accuracy of simple potential evapotranspiration estimate methods is presented. Those models will be adjusted locally through error autocorrelation analyses and linear regression in comparison with the standard FAO-Penman-Monteith method. This modeling strategy based on the combined application of several models is generally referred to as hybrid modeling in the literature (Solomatine and Price, 2004; Jain and Kumar, 2007; Abudu et al., 2011).

As the proposed methodology is based on FAO-Penman-Monteith estimates, all the necessary climatological data will still be needed for the calibration of local models. This issue seems to present a limitation of the proposed method for real-life applications. However, the intended audience is the small farmers or public departments that have no continuous access to the full data set of a complete climatological station. In this case, the agency responsible for the station operation can provide a simplified regional equation, which is based only on temperature data. The end users in the watershed need to operate only a single thermometer in order to get a good estimate of potential evapotranspiration.

\section{STUDY AREA}

This research was carried out with data from Jaboticabal city (Sao Paulo State), situated in the geo-

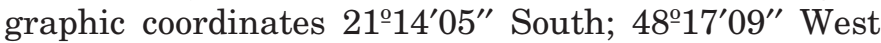
and $615 \mathrm{~m}$ of altitude. Following Köppen classification, the climate in the region is defined as humid subtropical with summer rains, showing a variation to tropical climate with dry winter. The rainiest trimester in the region occurs between January and March with approximately $43 \%$ of the annual precipitation. The driest trimester is from July until September, with only $8 \%$ of the annual precipitation. The annual average for precipitation is $1,424.6 \mathrm{~mm}$, for potential evapotranspiration is $1,487.8 \mathrm{~mm}$, for relative humidity is $70.8 \%$, and for temperature is $22.2^{\circ} \mathrm{C}$.

The meteorological data for this study have been supplied by the agroclimatologic station of University of the State of São Paulo (FCAV/UNESP).

\section{DESCRIPTION OF EVALUATED EMPIRICAL MODELS}

Empirical models use basic meteorological data, adjusted with soil and plant characteristics, to 
determine the potential evapotranspiration. Due to its easy application, these are useful methodologies to estimate the total amount of water lost in the soilplant-atmosphere system. However, generally the empirical methods are applicable only for long periods (Sediyama, 1996) and the exactness of the estimates is limited due to the dependence on few variables. Very common empirical methods are based on the air temperature as the main variable in substitution to the energy balance (Jacobs, 2001).

\section{FAO-Penman-Monteith Combined Method}

The original Penman method combined energy balance with mass transfer (aerodynamic) providing an equation to compute the open surface water evaporation. The estimate was based on standard climatologic records of sunshine period, temperature, humidity, and wind speed. This so-called combined method was further developed by many researchers and extended to cropped surfaces by introducing resistance factors. Presently, the Penman-Monteith equation is recognized as the standardized methodology (Allen et al., 1998) for potential evapotranspiration estimates. As this method is largely described in the literature, the equations will not be reproduced.

\section{Jensen-Haise Method}

The Jensen-Haise method (Jensen and Haise, 1963 ) is an empirical equation for the potential evapotranspiration calculation developed for arid and semiarid regions (Pereira et al., 1997). This equation uses the daily average temperature $\left(T,{ }^{\circ} \mathrm{C}\right)$ and global solar radiation data $\left(R_{\mathrm{s}}, \mathrm{mm} /\right.$ day $)$ to estimate the potential evapotranspiration (ETpJH, $\mathrm{mm} /$ day):

$$
E T p J H=R_{\mathrm{s}}(0.025 T+0.078) .
$$

The global solar radiation $\left(R_{\mathrm{se}}, \mathrm{MJ} / \mathrm{m}^{2} /\right.$ day $)$ can be converted into units of evaporated water $(\mathrm{mm} /$ day) by the relation:

$$
R_{\mathrm{s}}(\mathrm{mm} / \text { day })=\frac{R_{\mathrm{se}}\left(\mathrm{MJ} / \mathrm{m}^{2} \text { day }\right)}{\lambda},
$$

in which $\lambda=2.26 \mathrm{MJ} / \mathrm{m}^{2} / \mathrm{mm}$ is the latent heat of vaporization for water.

\section{Camargo Method}

Based on the Thornthwaite (1948) equation results, Camargo derived a new, simpler equation, however,
TABLE 1. Values of $K$ According to the Annual Average Temperature $\left(T_{\mathrm{a}}\right)$.

\begin{tabular}{lccc}
\hline $\boldsymbol{T}_{\mathbf{a}}\left({ }^{\circ} \mathbf{C}\right)$ & $\boldsymbol{K}$ & $\boldsymbol{T}_{\mathbf{a}}\left({ }^{\circ} \mathbf{C}\right)$ & $\boldsymbol{K}$ \\
\hline$<23.5$ & 0.0100 & $25.6-26.5$ & 0.0115 \\
$23.6-24.5$ & 0.0105 & $26.6-27.5$ & 0.0120 \\
$24.6-25.5$ & 0.0110 & $>27.5$ & 0.0130 \\
\hline
\end{tabular}

with similar efficiency (Camargo and Camargo, 2000). This methodology is recommended due to its easy computation:

$$
E T p C a m=K R_{\mathrm{s}} T N D,
$$

where ETpCam is the potential evapotranspiration ( $\mathrm{mm} /$ day), $T$ is the daily average temperature $\left({ }^{\circ} \mathrm{C}\right)$, $R_{\mathrm{S}}$ is the global solar radiation ( $\mathrm{mm} /$ day), $N D$ is the number of days of the evaluated period, and $K$ is an adjustment factor, which depends on the annual average temperature $\left(T_{\mathrm{a}}\right)$ of the study area as established in Table 1.

\section{STATISTIC ADJUSTMENT OF POTENTIAL EVAPOTRANSPIRATION EQUATIONS}

In order to improve the reliability of the simple models based on temperature and radiation data, an adjustment with the autocorrelation error and linear regression was elaborated having as reference the potential evapotranspiration estimated by the standard FAO-Penman-Monteith equation.

Statistical indices are used to compare different methodologies to the standard FAO-PenmanMonteith method. Camargo and Sentelhas (1997) suggested the following statistical indices:

precision given by Pearson correlation coefficient $r$

$$
r=\frac{\sum_{i=1}^{N}\left(O_{i}-O\right)\left(P_{i}-P\right)}{\sqrt{\sum_{i=1}^{N}\left(O_{i}-O\right)^{2}} \sqrt{\sum_{i=1}^{N}\left(P_{i}-P\right)^{2}}},
$$

accuracy given by Willmott index $d$

$$
d=1-\left[\frac{\sum_{i=1}^{N}\left(P_{i}-O_{i}\right)^{2}}{\sum_{i=1}^{N}\left[\left(P_{i}-O\right)+\left(O_{i}-O\right)\right]^{2}}\right],
$$

where $P_{i}$ is the estimated value, $O_{i}$ is the observed value, and $O$ is the average of the observed values. 
The index $d$ ranges from 0 to 1 , where the value 1 means a perfect accuracy of the estimated data, and the value 0 means that there is no accuracy.

The index proposed by Camargo (Camargo and Sentelhas, 1997) to express confidence or performance (c), is obtained as:

$$
c=r d
$$

An interpretation of the performance based on index $c$ is given in Table 2 .

In time series analysis, the root mean square error (RMSE) is probably the best measure of precision. RMSE is frequently used to evaluate the differences between values predicted by an estimator and the values actually observed, which in this case are the FAO-Penman-Monteith estimates.

$$
\operatorname{RMSE}=\sqrt[2]{\frac{\sum_{i=1}^{N}(P i-O i)^{2}}{N}}
$$

where $P_{i}$ is the estimated value, $O_{i}$ is the observed value, and $N$ is the number of observations.

The statistic evaluation has been performed with data available for the period between January 2002 and December 2006.

\section{Local Adjustment Based on Autocorrelation Error}

We consider that the empirical methods are a good approximation to the correct phenomena description and assume that the difference between these methods and real potential evapotranspiration is due to systematic errors that can be obtained as autocorrelation error.

Following this idea, the estimated potential evapotranspiration can be corrected as

$$
E T p_{a r(t)}=E T p_{t}+\left(c_{t}+\phi_{t} R_{t-1}\right)+\varepsilon_{t}
$$

in which $E T p_{\operatorname{ar}(t)}$ is the corrected potential evapotranspiration, $E T p_{t}$ is the potential evapotranspiration

TABLE 2. Criteria for Interpretation of the Performance Coefficient $c$ (Camargo and Sentelhas, 1997).

\begin{tabular}{clcl}
\hline "c" & Performance & "c" & Performance \\
\hline$>0.85$ & Excellent & 0.51 to 0.60 & Poor \\
0.76 to 0.85 & Very good & 0.41 to 0.50 & Bad \\
0.66 to 0.75 & Good & $\leq 0.40$ & Very bad \\
0.61 to 0.65 & Median & & \\
\hline
\end{tabular}

estimate by the original method, $c_{t}$ and $\Phi_{t}$ are constants obtained by autoregression, and $\varepsilon_{t}$ is a random error. The error $R_{t-1}$ is obtained from the difference

$$
R_{t-1}=\overline{E T p P M R s s_{t-1}}-E T p_{t-1},
$$

in which $\overline{E T p P M R s s}$ is an average potential evapotranspiration calculated by the standard FAOPenman-Monteith (for biweekly and monthly periods, from January 2002 to December 2006, as shown in Table 3) and $E T p_{t-1}$ is the potential evapotranspiration estimated by the original method for the preceding period $t-1$. The standard FAO-PenmanMonteith potential evapotranspiration ETpPMRss was calculated with estimated $R_{\mathrm{S}}$ (solar radiation) and measured average wind speed at $2 \mathrm{~m}\left(U_{2}\right)$. The error $R_{t-1}$ was evaluated for the period between 2002 and 2006 allowing the determination of the constants for the error autocorrelation model.

\section{Local Adjustment by Linear Regression}

Alternatively, the correction of estimated potential evapotranspiration has been carried out by linear regression to FAO-Penman-Monteith potential evapotranspiration, which was taken as a reference. The equation set has the following form:

$$
E T p_{r g}=\beta_{0}+\beta_{1} E T p+\varepsilon,
$$

in which $E T p_{r g}$ is the corrected potential evapotranspiration, $E T p$ is the potential evapotranspiration estimate by the original method, $\beta_{0}$ is a regression constant representing the intercession of the line with the $Y$-axis, $\beta_{1}$ is the regression coefficient that represents the variation of $Y\left(E T p_{r g}\right)$ in terms of changes in a unit of the variable $X$ (ETpPMRss), and $\varepsilon$ is a residual factor.

\section{OBTAINED RESULTS}

\section{Original Evapotranspiration Estimates Compared With FAO-Penman-Monteith}

The potential evapotranspiration estimates for both periods of analysis (biweekly and monthly) showed no significant discrepancy among them.

The original Jensen-Haise method showed bad results as it overestimates the FAO-PenmanMonteith potential evapotranspiration with RMSE = $23.6 \mathrm{~mm}$ for biweekly periods and $\mathrm{RMSE}=46.4 \mathrm{~mm}$ 
TABLE 3. Average Evapotranspiration Estimates $(\overline{E T o P M R s s}, \mathrm{~mm})$ for Biweekly and Monthly Periods Using the Penman-Monteith Method, From January 2002 to December 2006.

\begin{tabular}{|c|c|c|c|c|c|c|c|}
\hline Month & Day & $\overline{E T o P M R s s}(\mathbf{m m})$ & Month & Day & $\overline{E T o P M R s s}(\mathbf{m m})$ & Month & $\overline{E T o P M R s s}(\mathbf{m m})$ \\
\hline \multirow[t]{2}{*}{ January } & 15 & 61.4 & \multirow[t]{2}{*}{ July } & 15 & 34.0 & January & 126.7 \\
\hline & 31 & 65.3 & & 31 & 39.2 & February & 120.6 \\
\hline \multirow[t]{2}{*}{ February } & 15 & 63.8 & \multirow[t]{2}{*}{ August } & 15 & 44.5 & March & 123.8 \\
\hline & 28 & 56.8 & & 31 & 57.2 & April & 102.9 \\
\hline \multirow[t]{2}{*}{ March } & 15 & 64.2 & \multirow[t]{2}{*}{ September } & 15 & 57.4 & May & 79.1 \\
\hline & 31 & 59.6 & & 30 & 58.9 & June & 67.8 \\
\hline \multirow[t]{2}{*}{ April } & 15 & 54.0 & \multirow[t]{2}{*}{ October } & 15 & 63.2 & July & 73.3 \\
\hline & 30 & 48.9 & & 31 & 72.6 & August & 101.7 \\
\hline \multirow[t]{2}{*}{ May } & 15 & 39.3 & \multirow[t]{2}{*}{ November } & 15 & 72.2 & September & 116.3 \\
\hline & 31 & 36.6 & & 30 & 68.7 & October & 135.8 \\
\hline \multirow[t]{2}{*}{ June } & 15 & 34.5 & \multirow[t]{2}{*}{ December } & 15 & 62.8 & November & 132.8 \\
\hline & 30 & 33.8 & & 31 & 76.1 & December & 138.8 \\
\hline
\end{tabular}

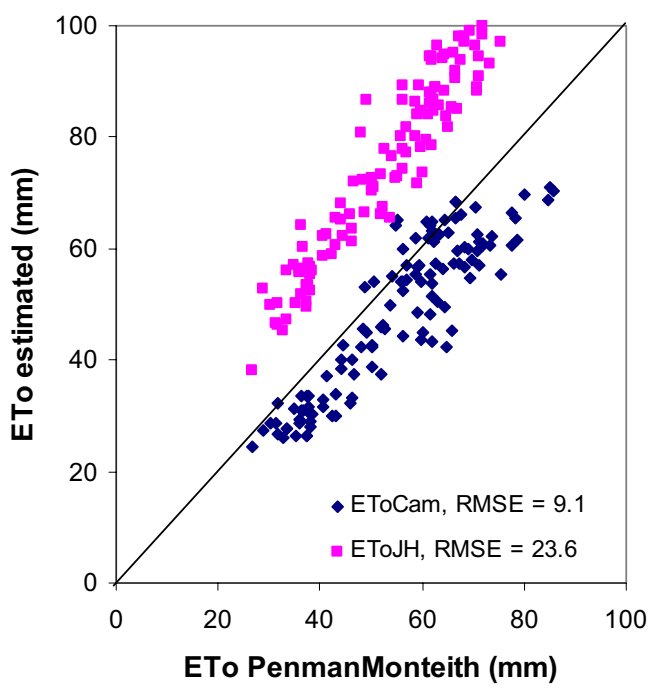

FIGURE 1. Potential Evapotranspiration Estimated by Camargo (EToCam) and Jensen-Haise (EToJH) Compared With the FAO-Penman-Monteith Results in Biweekly Analysis in the Period Between 2002 and 2006.

for monthly periods. Figure 1 shows the scatter plot comparing estimated values and the reference values for biweekly periods. For monthly estimates, the behavior is similar and the plot is not shown. Despite having an excellent correlation $(r=0.96$ and 0.97 for monthly and biweekly estimates, respectively), their values show a poor accuracy $(d=0.64$ and 0.61 for monthly and biweekly estimates, respectively). This poor behavior was expected as the equation was developed for arid and semiarid regions of the United States, where water supply requirements as irrigation for cultivation are larger than in a humid region like Jaboticabal.

The Camargo method presented a better performance (Figure 1), which could be expected, as this equation was derived from the Thornthwaite method for local conditions. However, the FAO-Penman-Monteith potential evapotranspiration was underestimated, on average, with $\mathrm{RMSE}=9.1 \mathrm{~mm}$ for biweekly periods and RMSE $=16.8 \mathrm{~mm}$ for monthly periods. In both cases, excellent statistical indices could be obtained $(r=0.90, d=0.89, c=0.80$ for biweekly period and $r=0.93, d=0.90, c=0.84$ for monthly period) indicating that the method is adequate for the region.

\section{Autocorrelation Error Analysis and Local Adjustment of the Equations}

Following the methodology proposed, the error between FAO-Penman-Monteith estimates and the analyzed methodologies has been determined allowing the definition of the correction equations by autoregression.

For the Camargo method, the obtained equations are

$$
\begin{aligned}
\operatorname{ETpCam}_{a r-15}= & \operatorname{ETpCam}[0.3491+4.3727 \\
& \left.\left(\operatorname{ETpCam}_{t-1}-\overline{\operatorname{ETpPMRss}}_{t-1}\right)\right], \\
\text { ETpCam }_{a r-30}= & \operatorname{ETpCam}+[10.545+0.2238 \\
& \left.\left(\operatorname{ETpCam}_{t-1}-\overline{\operatorname{ETpPMRss}}_{t-1}\right)\right]
\end{aligned}
$$

for biweekly and monthly periods, respectively.

For the Jensen-Haise method, the obtained equations are

$$
\begin{aligned}
E T p J H_{a r-15}= & E T p J H+[-21.4593+0.0573 \\
& \left.\left(E T p J H_{t-1}-\overline{E T p P M R s s}_{t-1}\right)\right],
\end{aligned}
$$




$$
\begin{aligned}
E T p J H_{a r-30}= & E T p J H+[-54.947-0.2094 \\
& \left.\left(E T p J H_{t-1}-\overline{E T p P M R s s}_{t-1}\right)\right]
\end{aligned}
$$

for biweekly and monthly periods, respectively.

$E T p C_{a m}$ means potential evapotranspiration estimated by the Camargo method adjusted locally by the autocorrelation error method $(\mathrm{mm}), E T p J H_{a r}$ means potential evapotranspiration estimated by Jensen-Haise adjusted locally by autocorrelation error method (mm), and $\overline{E T p P M R s s}$ (Table 3 ) is the average potential evapotranspiration estimated by the FAO-Penman-Monteith method for monthly or biweekly periods ( $\mathrm{mm}$ ).

\section{Linear Regression Analysis and Local Adjustment of the Equations}

As a second strategy, the different methodologies have been adjusted to the FAO-Penman-Monteith potential evapotranspiration by simple linear regression.

For the Camargo method, the obtained equations are

$$
\begin{aligned}
& E T p \operatorname{Cam}_{r g-15}=0.9369 E T p C a m+9.8065 \\
& E T p \operatorname{Cam}_{r g-30}=0.9227 E T p C a m+21.13
\end{aligned}
$$

for biweekly and monthly periods, respectively.

For the Jensen-Haise method, the obtained equations are

$$
\begin{aligned}
& E T p J H_{r g-15}=0.7403 E T p J H-2.5194, \\
& E T p J H_{r g-30}=0.7786 E T p J H-11.013,
\end{aligned}
$$

for biweekly and monthly periods, respectively.

EToCam $_{r g}$ is the potential evapotranspiration estimated by Camargo's method adjusted locally by the linear regression method $(\mathrm{mm})$ and $E T p J H_{r g}$ is the adjusted Jensen-Haise estimate ( $\mathrm{mm})$.

\section{Evaluation of the Adjusted Potential Evapotranspiration Estimates}

Using the adjusted equations, new estimates of potential evapotranspiration and comparative analysis with the reference given by FAO-Penman-Monteith were performed.

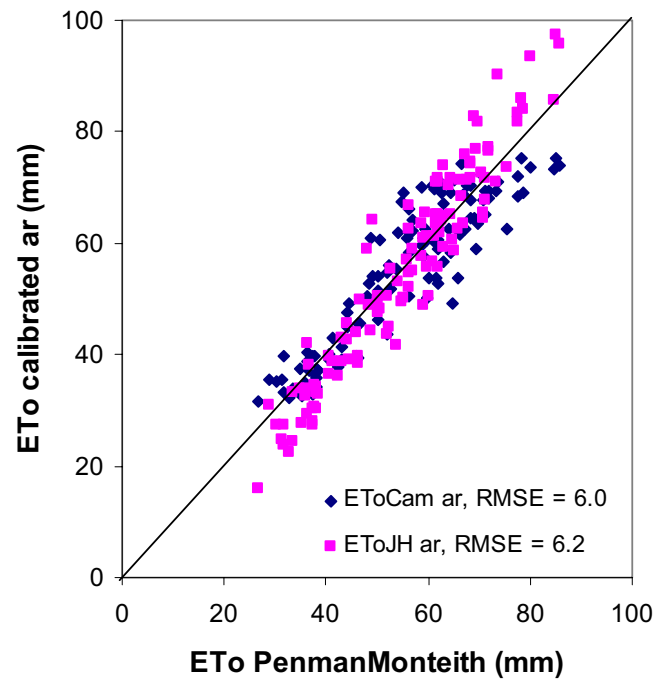

FIGURE 2. Potential Evapotranspiration Estimated by Camargo $\left(E T o C_{a m_{a r}}\right)$ and Jensen-Haise $\left(E T o J H_{a r}\right)$ Corrected by Autocorrelation Error Calibration Compared With the FAO-Penman-Monteith Results in Biweekly Analysis in the Period Between 2002 and 2006.

Figure 2 shows the scatter plot comparing estimated values adjusted by error autocorrelation and the reference values for biweekly periods.

After adjustment by local error analysis, the Camargo equation $\left(E T p C a m_{a r}\right)$ presented a large gain in the potential evapotranspiration estimate accuracy $(d=0.95$ and 0.97 for biweekly and monthly estimates, respectively). The good confidence has become even better ( $c=0.86$ and 0.91 for biweekly and monthly estimates, respectively). The corrected Camargo equation presented, on average, a small underestimate of potential evapotranspiration compared with FAO-Penman-Monteith (RMSE $=6.0$ and $9.3 \mathrm{~mm}$ for biweekly and monthly estimates, respectively).

The Jensen-Haise method adjusted by the autocorrelation error $\left(E T p J H_{a r}\right)$ showed a great improvement on the accuracy $(d=0.96$ and 0.97 for biweekly and monthly estimates, respectively) and performance $(c=0.92$ and 0.94 for biweekly and monthly estimates, respectively). Consequently, compared with the average FAO-Penman-Monteith potential evapotranspiration, the RMSE reduced to 6.2 and $10.0 \mathrm{~mm}$ for biweekly and monthly periods, respectively (Figure 2).

The results obtained with the equations adjusted by linear regression are shown in Figure 3 (scatter plot) in comparison with the reference values estimated for biweekly periods.

The Camargo equation adjusted by linear regression $\left(E T p C_{\text {Cam }}\right)$ showed the same indices as the error regression for biweekly estimate $(r=0.91$, $d=0.95, c=0.86$ ) and slightly better indices for monthly estimate $(r=0.93, \quad d=0.96, \quad c=0.89)$. 


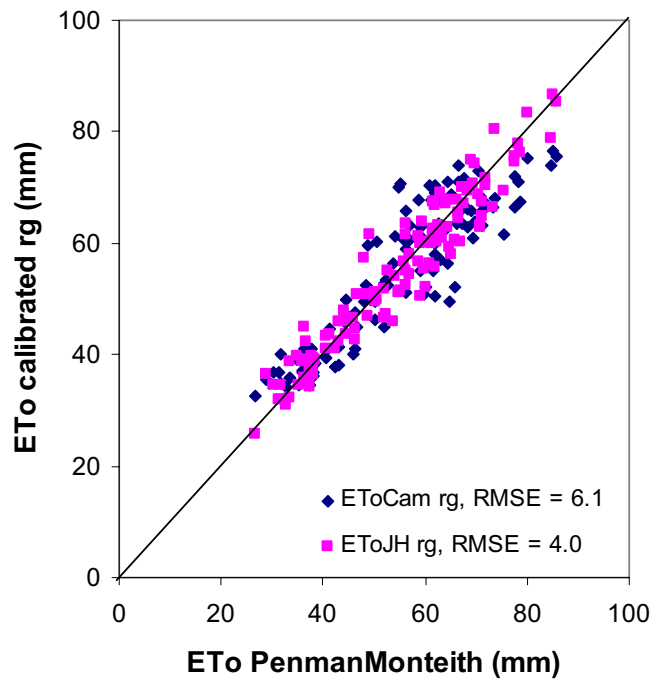

FIGURE 3. Potential Evapotranspiration Estimated by Camargo $\left(E_{T o} \operatorname{Cam}_{r g}\right)$ and Jensen-Haise $\left(E T o J H_{r g}\right)$ Corrected by Linear Regression Compared With the FAO-Penman-Monteith Results in Biweekly Analysis in the Period Between 2002 and 2006.

However, the average estimated potential evapotranspiration is a little bit worst in comparison with the reference method, with $\mathrm{RMSE}=6.1$ and $9.6 \mathrm{~mm}$ for biweekly and monthly estimates, respectively.

The linear regression fit for the Jensen-Haise method $\left(E T p J H_{r g}\right)$ was even better, showing good indices for comparison both in biweekly $(r=0.96$, $d=0.98, c=0.94$ ) as well as monthly estimates $(r=0.97, d=0.98, c=0.95)$. In comparison with the FAO-Penman-Monteith values, the RMSE reduced to 4.0 and $6.4 \mathrm{~mm}$ for biweekly and monthly periods, respectively. The linear regression for the JensenHaise method showed the overall greatest improvement. The estimate by the original Jensen-Haise method already showed a good correlation with the reference methodology, requiring only a good adjustment for local conditions.

Table 4 summarizes the evaluated statistic data for biweekly estimates in the period between 2002 and 2006.

TABLE 4. Correlation Coefficient $(r)$, Accuracy $(d)$, Performance (c), and Root Mean Square Error (RMSE) for Biweekly Periods Using Camargo (EToCam) and Jensen-Haise (EToJH) Equations With Autocorrelation Error (ar) and Linear Regression ( $r g$ ) Correction, From January 2002 to December 2006.

\begin{tabular}{lcccc}
\hline Equation & $\boldsymbol{r}$ & $\boldsymbol{d}$ & $\boldsymbol{c}$ & RMSE (mm) \\
\hline EToCam $_{\text {EToCam }}$ & 0.90 & 0.89 & 0.80 & 9.1 \\
EToCam $_{r g}$ & 0.91 & 0.95 & 0.86 & 6.0 \\
EToJH $_{\text {EToJH }}$ & 0.91 & 0.95 & 0.86 & 6.1 \\
EToJH $_{r g}$ & 0.96 & 0.64 & 0.61 & 23.6 \\
\hline
\end{tabular}

\section{Validation of the Methodology With Different Data}

Climatic data collected for the Year 2001 were purposely left out of the autocorrelation analysis, so they can be used to verify the effective adjustment beyond the period considered in the error autocorrelation and linear regression.

In order to evaluate the effectiveness of the proposed corrections, the potential evapotranspiration for the Year 2001 was estimated with the equations in their original and adjusted forms and compared with the standard FAO-Penman-Monteith estimate.

The estimated potential evapotranspiration with the original Camargo method for the Year 2001 showed (Figure 4) better coefficients $(d=0.91$ and RMSE $=8.3 \mathrm{~mm}$ for biweekly estimates) than the average of subsequent years (discussed previously). The adjusted equations by error autocorrelation and linear regression, however, could still improve the estimates with RMSE $=3.6$ and $3.9 \mathrm{~mm}$, respectively. The accuracy increased to $d=0.98$ proving the calibration effectiveness.

The estimated potential evapotranspiration with the original Jensen-Haise method $(d=0.61$ and RMSE $=23.6 \mathrm{~mm}$ for biweekly estimates) for the Year 2001 appeared to overestimate (Figure 5) the reference method again. However, due to the good correlation $(r=0.98)$, the adjusted equations could improve the accuracy $(d=0.96$ and RMSE $=6.5 \mathrm{~mm}$ for the error autocorrelation and $d=0.98$ and $\mathrm{RMSE}=3.1 \mathrm{~mm}$ for linear regression) in biweekly

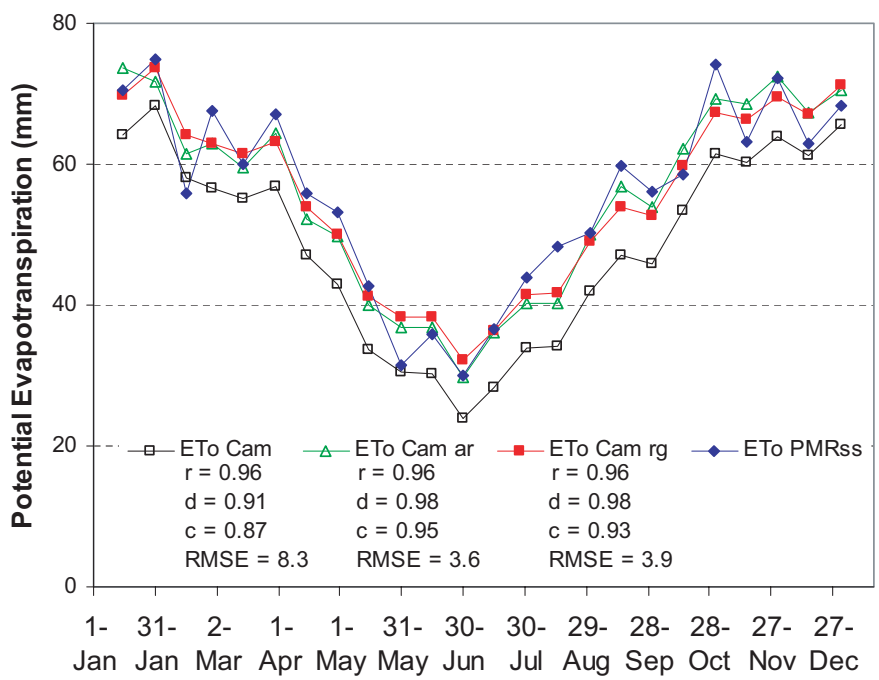

Date (2001)

FIGURE 4. Comparison Between Potential Evapotranspiration Estimated by Camargo (EToCam, RMSE $=8.3$ ), With Autocorrelation Error $\left(E T o C_{a m}\right.$ ar RMSE = 3.6), Linear Regression $\left(\right.$ EToCam $_{r g}$, RMSE $=3.9$ ), and by FAO-Penman-Monteith (EToPMRss) Methods in Biweekly Period for the Year 2001. 


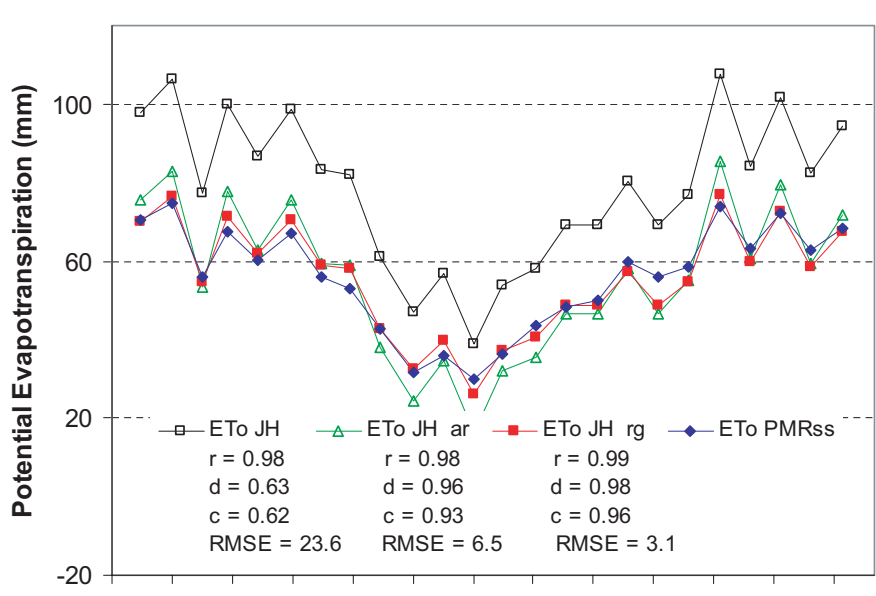

1- 31- 2- 1- 1- 31- 30- 30- 29- 28- 28- 27- 27Jan Jan Mar Apr May May Jun Jul Aug Sep Oct Nov Dec

Date (2001)

FIGURE 5. Comparison Between Potential Evapotranspiration Estimated by Jensen-Haise $(E T o J H, \mathrm{RMSE}=23.6)$, With Autocorrelation Error $\left(E T o J H_{a r}, \mathrm{RMSE}=6.5\right)$, Linear Regression (ET$o J H_{r g}, \mathrm{RMSE}=3.1$ ), and by FAO-Penman-Monteith (EToPMRss) Methods in Biweekly Period for the Year 2001.

periods. For monthly periods, the behavior is similar. The fit by linear regression showed excellent performance with $c=0.97$.

The proposed methodology for adjustment of the local potential evapotranspiration equations by the autocorrelation error method showed a large gain in performance, but mainly on the accuracy $(d-$ index of Willmott). Although the adjustment by autocorrelation error provided improvements in the adjusted methodology, the efficiency was greater when an excellent correlation was present.

In most cases, equations corrected by linear regression estimated as well or better than the autocorrelation error correction. This result indicates that this type of adjustment is more desirable due to its simplicity and good results. However, in order to obtain a good performance for the adjustment by linear regression, the original methodology has to present an excellent correlation with the reference methodology (FAO-Penman-Monteith).

Both methods achieved excellent gains with the proposed correction; however, the Jensen-Haise method appears to be the more suited when a good correlation is available, despite the initially poor accuracy.

\section{CONCLUSIONS}

Two simple methods for potential evapotranspiration estimate based on temperature and global solar radiation were analyzed, in order to define the most appropriate model for the study region. The equations were evaluated in comparison with the reference FAO-Penman-Monteith estimates. A methodology based on error autocorrelation and linear regression has been proposed for local estimates improvement. The analysis has been performed for monthly and biweekly estimates of potential evapotranspiration and the obtained results enabled the following conclusions.

The original Camargo (1971) methodology presented excellent performance compared with potential evapotranspiration estimates by FAO-PenmanMonteith. The original Jensen and Haise (1963) method obtained unsatisfactory performance.

The Jensen and Haise (1963) and Camargo (1971) equations provided excellent adjustments by the error autocorrelation correction. However, the linear regression is recommended in this region due to its simplicity and excellent obtained results. The obtained results also indicate that the radiation is the more important climatic variable for potential evapotranspiration estimate in the region.

The proposed methodology works properly for empirical methods that present poor accuracy but good correlation with the reference method (PenmanMonteith). The calibrated equations provide an interesting tool for potential evapotranspiration estimate in locations with few data (e.g., temperature) representing an important alternative for end users in poorly gauged basins.

\section{ACKNOWLEDGMENTS}

The authors are grateful to the unknown reviewers and associate editor for their comments and suggestions, which greatly improved the quality of the article. This study was supported by the Brazilian National Research Council (CNPq/Brazil).

\section{LITERATURE CITED}

Abudu, S., J.P. King, and S. Bawazir, 2011. Forecasting Monthly Streamflow of Spring-Summer Runoff Season in Rio Grande Headwaters Basin Using Stochastic Hybrid Modeling Approach. Journal of Hydrologic Engineering 16(4):384390.

Allen, R.G., L.S. Pereira, D. Raes, and S. Martin, 1998. Crop Evapotranspiration. FAO, Rome, 297 pp. (FAO, Irrigation and Drainage Paper, 56).

Barreto, C.E.A.G., E. Wendland, and F.F.N. Marcuzzo, 2009. Estimativa da evapotranspiração a partir de variação de nível estático de aquífero. Engenharia Agrícola 29(1):52-61, doi: 10.1590/S0100-69162009000100006.

Camargo, A.P., 1971. de. Balanço hídrico no Estado de São Paulo. Campinas: Instituto Agronômico, 24 pp. Boletim 116.

Camargo, A.P. and M.B.P. Camargo, 2000. Uma revisão analítica da evapotranspiração potencial. Bragantia 59(2):125-137. 
Camargo, A.P., F.R. Marin, P.C. Sentelhas, and A.G. Picini, 1999. Ajuste da equação de Thornthwaite para estimar a evapotranspiração potencial em climas áridos e superúmidos, com base na amplitude térmica diária. Revista Brasileira de Agrometeorologia 7(2):251-257.

Camargo, A.P. and P.C. Sentelhas, 1997. Avaliação do desempenho de diferentes métodos de estimativa da evapotranspiração potencial no estado de São Paulo, Brasil. Revista Brasileira de Agrometeorologia 5(1):89-97.

Chiew, F.H.S., N.N. Kamaladasa, H.M. Malano, and T.A. McMahon, 1995. Penman-Monteith, FAO-24 Reference Crop Evapotranspiration and Class-A Pan Data in Australia. Agricultural Water Management 28(1):9-21.

Granger, R.J. and D.M. Gray, 1989. Evaporation From Natural Non-Saturated Surfaces. Journal of Hydrology 111:21-29.

Jacobs, J.M., 2001. Evaluation of Reference Evapotranspiration Methodologies and AFSIRS Crop Water Use Simulation Model. Dissertation, University of Florida, Gainesville, Florida, 114 pp.

Jain, A. and A.M. Kumar, 2007. Hybrid Neural Network Models for Hydrologic Time Series Forecasting. Applied Soft Computing, 7(2):585-592.

Jensen, M.E., R.D. Burman, and R.G. Allen, 1990. Evapotranspiration and Water Irrigation Requirements. Committee on Irrigation Water Requirements, Irrigation and Drainage Division of ASCE, Manual No. 70, ASCE, New York, 329 pp.

Jensen, M.E. and H.R. Haise, 1963. Estimating Evapotranspiration From Solar Radiation. Journal of Irrigation and Drainage Division, ASCE 89:15-41.

Liu, J. and K. Kotoda, 1998. Estimation of Regional Evapotranspiration From Arid and Semi-Arid Surfaces. Journal of the American Water Resources Association 34:27-41, doi: 10.1111/ j.1752-1688.1998.tb05958.x.

López-Urrea, R., F. Martín de Santa Olalla, C. Fabeiro, and A. Moratalla, 2006. Testing Evapotranspiration Equations Using Lysimeter Observations in a Semiarid Climate. Agricultural Water Management 85:15-26.

Lu, J., G. Sun, S.G. McNulty, and D.M. Amatya, 2005. A Comparison of Six Potential Evapotranspiration Methods for Regional Use in the Southeastern United States. Journal of the American Water Resources Association 41:621-633, doi: 10.1111/j.17521688.2005.tb03759.x.

Makkink, G.F., 1957. Testing the Penman Formula by Means of Lysimeters. International Journal of Water Engineering 11:277288.

Pereira, A.R. and W.O. Pruitt, 2004. Adaptation of the Thornthwaite Scheme for Estimating Daily Reference Evapotranspiration. Agricultural Water Management 66:251-257.

Pereira, A.R., N.A. Villa Nova, and G.C. Sediyama, 1997. Evapo(transpi)ração. FEALQ, Piracicaba, 183 pp.

Priestley, C.H.B. and R.J. Taylor, 1972. On the Assessment of Surface Heat Fluxes and Evaporation Using Large-Scale Parameters. Monthly Weather Review 100:81-92.

Ross, M., J. Geurink, A. Said, A. Aly, and P. Tara, 2005. Evapotranspiration Conceptualization in the HSPF-MODFLOW Integrated Models. Journal of the American Water Resources Association 41:1013-1025, doi: 10.1111/j.1752-1688.2005. tb03782.x.

Sediyama, G.C., 1996. Estimativa da evapotranspiração: Histórico, evolução e análise crítica. Revista Brasileira de Agrometeorologia 4(1):1-12.

Solomatine, D.P. and R.K. Price, 2004. Innovative Approaches to Flood Forecasting Using Data Driven and Hybrid Modeling. In: Proceedings of the 6th International Conference on Hydroinformatics, S. Liong, K. Phoon and V. Babovic, (Editors). World Scientific, Singapore, pp. 1639-1646.

Sumner, D. M., 2006. Adequacy of Selected Evapotranspiration Approximations for Hydrologic Simulation. Journal of the
American Water Resources Association 42:699-711. doi: 10.1111/ j.1752-1688.2006.tb04486.x.

Thornthwaite, C.W., 1948. An Approach Toward a Rational Classification of Climate. Geographical Review 38(1):55-94.

Wendland, E., C. Barreto, and L.H. Gomes, 2007. Water Balance in the Guarani Aquifer Outcrop Zone Based on Hydrogeologic Monitoring. Journal of Hydrology 342(3-4):261-269, doi: 10.1016/ j.jhydrol.2007.05.033.

Xu, C.-Y. and D. Chen, 2005. Comparison of Seven Models for Estimation of Evapotranspiration and Groundwater Recharge Using Lysimeter Measurement Data in Germany. Hydrological Processes 19:3717-3734. 